\title{
Stereotypes in Disguise: The Dual School Lives of Japanese Immigrant Students
}

\author{
Yukari Takimoto Amos \\ Central Washington University \\ USA
}

This study investigated how Japanese adolescents behaved and performed in differing educational contexts. A qualitative analysis of 12 male and 11 female students revealed that they were quiet and reserved and fit the model minority stereotype while attending public/private schools in an urban region of the northwestern part of the United States. In contrast, at a Japanese weekend school the same students were relaxed, loud, and careless about academic performance. The findings of the study suggest a unique function of an ethnic language school beyond the maintenance of language and culture.

Theoretical Framework: An Ethnic Language and Identity

\section{Setting and Methods}

Results

Discussion

References

Appendices

A stereotype is defined as "something conforming to a fixed or general pattern" (Merriam-Webster's Collegiate Dictionary, 2003, p. 1224). Racial/ethnic minorities have been historically stereotyped and have contended with socially fixed notions in the United States. For example, Asian Americans have been stereotyped as model minorities. This stereotype praises Asian Americans who are accepted into White middle-class society by overcoming adversity through the presumed strengths of their cultural backgrounds and the gifts of their individual talents, such as high intellectual abilities, academic achievement, social conformity, and political passivity (Sue \& Okazaki, 1990; Suzuki, 1980).

Stereotypes, however, have repercussions for the groups of people they are applied to. Research on Asian Americans (Lee, 1996, 2005; Lew, 2006) suggests the danger of the model minority stereotype. The stereotype ignores the variability of Asian students in terms of ethnicity, socio-economic status, and immigration experiences and causes resentment from other minority groups. Importantly, the stereotype also ignores the existence of White racism towards Asians.

In spite of these shortcomings, the model minority stereotype is prevalent in the United States. At school Asian students are often described as shy, quiet, silent, studious, diligent, hardworking, and high achievers. They are underrepresented in special education (Jan, 2008; Poon-McBrayer \& Garcia, 2000) and overrepresented in gifted education. 
It is widely publicized that many Japanese students do well academically in international competitions (U. S. Department of Education, 2004), yet what is not explained is the fact that dropouts and academic problems do occur even among them. In addition, research vividly documents that Japanese classrooms, particularly at the elementary level, are extremely noisy and loud with active academic and social engagement (Tobin, Wu, \& Davidson, 1989; Suzuki, 2000). This suggests that Japanese students are far from being shy and quiet in nature.

What distinguishes most saliently between Japanese in the United States and Japanese in Japan is the majority/minority status. Japanese in the United States are vulnerable to the stereotype assigned to them by the dominant group due to their minority status. On the other hand, Japanese in Japan are the majority and have the privilege of creating and perpetuating stereotypes about minority groups in Japan. I would argue that this status difference does make a difference in how people behave and perform at school.

The purpose of this research is to investigate whether or not Japanese students manifest different behavior and performance patterns at a place where they can be the majority in the United States, as opposed to schooling where they are an ethnic minority. Does the majority/minority status influence how they behave and perform academically?

\section{Theoretical Framework: An Ethnic Language and Identity}

Ethnic communities typically establish social institutions, such as schools, for their immigrant children. The purpose of these ethnic schools is to preserve their cultural heritage against the massive assimilation force of the dominant host culture. This is because the parents are afraid to see their children lose their ethnic cultural traits. If schools are perceived as transmitting culture, both overtly and covertly, they are more likely to transmit the culture and values of the dominant group. Although learning the language and culture of a host country through schooling is necessary to accomplish social mobility in the host country, immigrant parents do not abandon the primordial attachment to their ethnic group.

For language minority groups, the preservation of ethnic languages is of utmost importance since language is a crucial element of ethnicity for most groups (Padilla, 1999) and the vehicle for socialization (Jourdan \& Tuite, 2006). In order to preserve this crucial element, minority groups historically established both public and private language schools in the United States. For example, the Jewish all-day school grew significantly from the mid-1910s to the 1930s and offered Jewish studies (Morimoto, 1997). The first Chinese language school appeared in San Francisco's Chinatown in 1884 (Zhou \& Li, 2003). The first Japanese language school was established in 1902 in California during antiJapanese sentiment (Asato, 2006). 
The main purpose of ethnic language schools has been to teach ethnic languages and cultures. Yet it has also helped to create and nurture a sense of "we-ness," in other words, ethnic identity (Zhou \& Li, 2003). For example, Asato (2006) claims that the Japanese language school experience helped construct Nisei identity more than learning the language itself. Language is used to convey the values of the group and necessarily establish in-group and out-group boundaries (Padilla, 1999). Ultimately, language contributes to the social and psychological processes involved in the formation of ethnic identity (Fought, 2006). At ethnic language schools students are exposed to things that are dramatically different from what they experience at regular schools. They speak, listen, read, and write in their ethnic languages, which are incomprehensible to outsiders. They are taught traditional family values, which might be very different from those of the dominant culture. They are physically surrounded by members of their own ethnic group, something that in most cases does not occur at their regular schools. By experiencing and appreciating many things from their native heritage with members of their own ethnic group, a sense of "we-ness" naturally emerges. Ethnic identity is a sense of "we-ness"; it is "the degree to which a person feels connected with a racial and/or culture group that is important to one's family" (Bennett, 2007, p. 89) and "one's sense of belonging to an ethnic group and the part of one's thinking, perceptions, feelings, and behavior that is due to ethnic group membership" (Rotheram \& Phinney, 1987, p. 13).

\section{Setting and Methods}

Qualitative inquiry techniques were used in this study. All the student participants met the following criteria: their parents are both immigrants from Japan (post-1965) with little intention of returning to their homeland, and they all had a dual schooling experience (U.S. schools and a Japanese school). The Japanese community in the Seattle area provides a special educational opportunity for Japanese children: the Seattle Japanese School. The students attend U.S. schools Monday through Friday and the Japanese school on Saturday. It was established in 1971 by the Japanese government and had 526 students and 54 teachers as of June 2007 (The Seattle Japanese School, 2008). It includes a kindergarten, an elementary school, a junior high school, and a high school, and those who are fluent in the Japanese language are admitted. Although the purpose of the school is to prepare those who are sojourning in the United States for a smooth transition back to the Japanese public education system, student participants in this study who had little intention of returning to Japan in the future were also admitted.

The study involved 23 Japanese adolescents: 12 males and 11 females who attended different U.S. schools (nine public middle/junior high schools, seven public high schools, and three private schools). Erikson (1980) describes adolescence as a period in the life cycle when identity vs. confusion is prominent. This is the time when individuals search for who they are. Minoura's (1984) study, referring to both Piaget and Erikson, hypothesized that the most important 
period for Japanese children to acquire cultural meanings is between 9 and 15 years old. Using these guidelines, the study investigated Japanese adolescents whose ages ranged from 11-17 years, and whose school grades were approximately 6-10. A summary of the participants is presented in Table 1 (see Appendices). The study also included 11 teachers at both U.S. and Japanese schools. Their background is summarized in Table 2 (see Appendices). All the participants' names are pseudonyms.

This research project required intense study of a few participants rather than less in-depth study on a large number of participants. The purpose of qualitative research is not to produce generalizations by working with large populations (Bogdan \& Biklen, 2007). The main data sources of this study were observations and interviews. The student participants were observed multiple times in their classes, during lunch, and at recess in both the U.S. and the Japanese schools. The researcher observed the students first and then interviewed them individually in a semi-structured format. They were also asked to share their essays and letters with her. The teachers were also interviewed. All the interviews were tape-recorded and transcribed. The interview transcriptions and other data, such as field notes and essays, were coded and analyzed. Common themes, patterns, and propositions that surfaced from the data analyses were used to organize the findings.

\section{Results}

The results of the study are presented in two categories: behaviors and academic performance in two different educational contexts: U.S. schools and the Japanese school.

\section{Behaviors in U.S. Schools}

All the U.S. schools the participants attended were predominantly White and had little ethnic/racial diversity. In general, the participants were the only Japanese and were isolated in terms of ethnic group membership. Since they could not socialize with members of their own ethnic group, these students mingled with friends who were ethnically and racially different from themselves.

All of the participants socialized well. This was confirmed by observation in school. The Japanese students were amiable in talking, playing, and studying with peers from different ethnic/racial groups inside and outside of classrooms. Ichiro's lunch time peers included Whites and Koreans. Kuro $\left(9^{\text {th }}\right.$ grade male) and Hachiro ( $7^{\text {th }}$ grade male) played basketball every morning before class with Whites, African Americans, and Asian Americans. Natsuko's ( $6^{\text {th }}$ grade female) close friends included two Whites, a Filipino American, and a girl who was part Chinese and European American. 
Their teachers confirmed that the participants got along well with almost everyone in class. Natsuko's teacher (David) praised her and commented, "Very well socialized. I think she has friends, just from the entire class." Rokuro's $\left(8^{\text {th }}\right.$ grade male) teacher (Julie) also stated that he was "very social with his friends."

Yet, being social did not necessarily indicate that the participants were noisy and loud or stood out among peers. Rather, they were quiet and reserved. Although Akiko ( $8^{\text {th }}$ grade female) cheerfully socialized with her friends before class, she did not raise her voice among peers and tended to smile silently. During snack time Hichiro ( $8^{\text {th }}$ grade male) kept wandering among peers and softly exchanging only a few sentences with them. None of them intentionally distracted teachers and peers. They were so-called "good" students.

The observed quietness of the participants was confirmed by their teachers. Yoko's ( $9^{\text {th }}$ grade female) teacher (Mary) described her as "very quiet." His teacher (Jerry) characterized Juichiro $\left(10^{\text {th }}\right.$ grade male $)$ as "compliant and very quiet." Hichiro's teacher (Elizabeth), who had known him for eight years, indicated that he did "not speak up enough" in class and that she always needed to encourage him to ask questions.

This characteristic of quietness was also self-reported by the students themselves. Tomoko ( $7^{\text {th }}$ grade female) stated, "I am very quiet at the U.S. school." Reiko ( $11^{\text {th }}$ grade female) declared, "Well, I don't stand out at the U.S. school. I don't talk a lot." Haruko's ( $8^{\text {th }}$ grade female) comment was rather selfprotective. She confessed, "I don't want to stand out among peers at the U.S. school. I would rather be quiet and reserved. Why? I don't want American peers to pick on me. Don't talk and just listen."

Their quietness was partially a result of teasing all of them experienced. One example was their lunch. Sachiko $\left(10^{\text {th }}\right.$ grade female) and Kuro reported the occasions when they opened their lunch. Their peers reacted with, "What is it? It's strange!" They said Haruko's lunch "looked like food for birds." Etsuko's ( $8^{\text {th }}$ grade female) peers screamed, "She's eating seaweed!" Rokuro's peers commented, "It sucks! The taste of seaweed is awful!" In addition to making derogatory remarks about their lunch, their peers continued to gaze at the contents of the lunch, which embarrassed the participants and made them hide their lunch in shame. To the American students who were not accustomed to it, onigiri (rice ball) with kuro nori (black dried seaweed) was strange food. Yet, this item is the most popular and common food for lunch that Japanese mothers prepare for their school-aged children. Reiko mentioned, "My peers kept watching me eating onigiri."

The unpleasant teasing about their cultural cuisine made the participants respond in a defensive way. Almost all of them asked their mothers to stop packing Japanese food for lunch and to prepare Western food instead, such as sandwiches and bagels. Chikako $\left(10^{\text {th }}\right.$ grade female $)$ explained, "I buy lunch at 
school or bring sandwiches now. I was once so embarrassed when I brought my Japanese-style lunch." Tomoko confessed, "I don't have confidence in eating Japanese food at school." Sachiko remembered being "shocked" by her peer's reactions. She "swore not to bring Japanese-style lunch to school again" because she was hurt very much.

The participants' English caused additional teasing. Although all the participants said that they were more confident in English than Japanese, it did not necessarily indicate that they were able to use English like native speakers. Most students confessed that they had experienced problems regarding the English language. The problem dealt primarily with pronunciation, accent, and their feelings of inferiority. In commenting on these difficulties, Kuro laughed at himself and said, "My friends always tease me and say that my pronunciation sounds strange." Although constantly code-switching, Haruko sadly said:

When I was in the third grade, I couldn't pronounce the "th" sound, for example, "three" and "thirteen" properly. Friends made fun of me saying, "Say thirteen." I almost cried in front of them. I wanted to yell at them, "So, can you even sound out some Japanese words, can't you?"

The "th" sound does not exist in the Japanese language phonetics. So, when the students began to learn proper pronunciation in English at school, the "th" sound was particularly problematic.

No matter how well they seemed to function in English the internal fears and feelings of inferiority about their English proficiency were always in their minds. Fuyuko's ( $9^{\text {th }}$ grade female) academic grades were excellent, and she was more fluent in English than in Japanese. Yet, she explained, "I think my English is almost perfect. But, compared to American peers, I sometimes feel my English is not quite as perfect as theirs." Saburo ( $9^{\text {th }}$ grade male), quoting his teacher's comments, confessed:

I can't say that my English is perfect. Americans speak English very fast. I can't keep up with their speaking speed. Particularly, African Americans. They speak English like a machine gun. Gan, gan, gan [loud and fast clanging sound]!

\section{Academic Performance in U.S. Schools}

At the U.S. schools, the students felt that school was fundamentally a place to study. With the exception of Saburo, everyone showed a determination to succeed academically and had attained a high level of academic achievement. Most of them were enrolled in honors or advanced classes, particularly in mathematics. The followings are examples of comments they made about their academic performance: 
Tomoko: I've got all 4.0s. I'm in the $7^{\text {th }}$ grade, but I attend the $8^{\text {th }}$ grade math class. I feel so good about myself whenever I think that I'm the only student who takes the $8^{\text {th }}$ grade math class among the $7^{\text {th }}$ graders.

Fuyuko: I make an effort to get straight A's.

The model minority stereotype fit the students well. They studied hard, performed better than their peers, and succeeded academically. Their teachers agreed that the participants were model students. Praising Tomoko, her language arts teacher (Nancy) stated, "Tomoko is an excellent student. She participates and listens well. She's very considerate of others. A model student!" David (social studies teacher) and Mary (religion and math teacher), who had taught Haruko in the past, depicted her performance as follows:

David: I don't think Haruko has ever received anything but an "A" on her report card.

Mary: I don't think so, either. Works very, very hard.

David: She has an incredible work ethic.

Whenever they talked about their academic achievement, the participants automatically compared themselves to Americans. It seems that the desire to outperform the American peers motivated them to study harder. The participants also perceived American students as not studying hard enough. Shiro $\left(9^{\text {th }}\right.$ grade male) contended, "There are not many Americans who make an effort to succeed academically." Chikako added, "There are many Americans who don't care about their grades. They don't care about their studies. I hate to see those students." The participants' assumption that they were academically superior was confirmed in classes, particularly in mathematics. They thought that studies at the U.S. schools were far easier than those at the Japanese school and reported that the Japanese school offered more difficult and advanced concepts in mathematics than the U.S. schools. Hichiro confessed, "Mathematics at the U.S. schools was like reviewing what I already learned at the Japanese school long time ago."

The racial/ethnic composition of the students in advanced classes further strengthened their feeling of superiority. The participants found themselves among different Asian ethnic groups, such as Chinese and Korean, in most of their advanced classes. For instance, in Juro's ( $8^{\text {th }}$ grade male) advanced algebra class, "more than 50 percent of students were Asians." He explained that advanced and challenging classes in any subject at his U.S. school had a high proportion of Asian students. The high concentration of Asian students in advanced classes at a predominantly White school convinced the participants 
that Asians were academically superior. Juro proudly said, "There is a stereotype about Asians being smart. But looks like it is true."

Teachers also fostered the stereotype. Chikako recalled her ESL teacher's praise about Asian students. The teacher asserted, "Asian students voluntarily study on their own and have good study habits." Chikako remembered that she was content with this statement. Hichiro described his mathematics class as follows:

The seats are always assigned by the teacher. He intentionally assigns my seat between those who are not good at math because he wants me to help them. He knows I am good at math and believes that my classmates will be happier if I teach them rather than he teaches them.

The classroom observation confirmed Hichiro's comment. His mathematics teacher kept directing questions only to Hichiro, and Hichiro continued to give correct answers. The teacher proudly showed Hichiro's mathematics notebook to the researcher and declared, "He is an outstanding and exemplary student. He is very different from other students."

The students were keenly aware of the expectation from the adults. All of them but Saburo agreed that they must study hard for success. They felt a necessity to please their parents and teachers by living up to their high expectations. Shiro answered, "My teachers expect me to get good grades. I am pleased with their expectation and want to please them more." Goro $\left(8^{\text {th }}\right.$ grade male) mentioned that he regretted not studying hard enough whenever he received an average grade.

Distinguished academic performance yielded self-confidence among the students. They found pleasure in being confident and feeling good about themselves by succeeding academically. Chikako declared, "I can boast about my good grades and be proud of myself when I get a good grade. It's like, 'I can do this much!" Describing the mathematics contest she had participated in, Haruko was excited to tell, "I was awarded the first prize! I felt so good about myself." Fuyuko explained, "Good grades are important to maintain my pride."

Yielding high self-confidence was not limited to academics. They also expanded it to personality characteristics. Yoko won the award presented to the most inspirational girl in the freshman class. She asserted, "I think people like me. It's good to be liked by everyone. I felt so good about myself." Fuyuko contended, "My volleyball team won the contest due to our good teamwork. It's important to have a good relationship with people. I want everybody to like me."

The students were sensitive to how other people thought of them. Their high self-confidence was reflective of how others positively evaluated them. Natsuko claimed, "I want to give people the impression that I am smart." Fuyuko 
declared, "I want to prove that even Asians can do this and that. But too much standing out is dangerous." Haruko was careful about her attitude trying not to offend others. She mentioned, "I don't want people to think of me as being arrogant and impudent. I want to be quiet among people. Don't talk and just listen." The students were careful about how others judged them and what they should do in order to gain positive evaluation. Attaining high academic performance was one means for gaining approval from others.

\section{Behaviors in the Japanese School}

Then, how did the students behave at the Japanese school? The Seattle Japanese School meets only on Saturdays. All of the participants were excited to go to the school. Since the school met only once a week, if they missed, they would have to wait for another week to see their Japanese friends. This was something they definitely wanted to avoid.

Unlike at the U.S. schools, classes, recess, and lunchtime were rather chaotic and noisy at the Japanese school. The same Japanese students who were quiet at the U.S. schools were far more active, lively, and engaging at the Japanese school. They were eager to ask questions of teachers in Japanese. When they did so, they either spoke spontaneously from their seats or yelled in a loud voice, "Hai, hai, hai (Yes, yes, yes)!" Sometimes their voices overlapped because more than two students spoke simultaneously, and the teachers could not understand what they were talking about. Teachers often had to raise their voice to calm the students down, yelling "Shizuka ni shinasai! (Be quiet!)" Giggling voices constantly fluttered around the classroom. Etsuko did not stop chatting with a boy in front of her seat during class, while Jujiro ( $7^{\text {th }}$ grade male) kept talking to himself and to the class in a loud voice without worrying about anything. When some students gave wrong answers or said something funny, other students responded with harsh and rude comments to them, which made the whole class burst into laughter.

They talked to teachers in a casual rather than a formal manner. Some of the students talked to their teachers as if the teachers were their close friends. For example, Jujiro almost made fun of his social studies teacher when he said, "likagen na sensei! Jugyou wo susumeyou! [You are such an irresponsible teacher! Let's move on to study!]" without using any honorific forms. Ichiro added, "Sensei! Jugyou ga hajimatte kara mou 15 fun dayo! [Teacher! It's been already 15 minutes since the starting bell rang!]." In Japan, students are taught to use honorifics to teachers and senior students when addressing them. This custom seemed to be foreign to the students.

Recess time was also rather boisterous. Unlike at the U.S. schools, the students did not need to move from classroom to classroom because they had their own homeroom, and teachers came to the room to teach. As a result, between classes, they had time to relax until the next class began. As soon as 
the bell rang, the students immediately stood up and wandered around the classroom or moved outside to chat with friends. Akiko and Etsuko immediately opened up Japanese comic books from their backpacks. Tomoko kept laughing with female friends for nothing. Gossiping about celebrities in the Japanese entertainment world was an important connection among peers. Yoko said that she "read Japanese comic books and magazines and watched Japanese TV programs" to keep her from lagging behind her peers. Loud voices and shrieking sounds never stopped during the recess time. Some of them, such as Juichiro, for example, were quiet even at the Japanese school. Among his annoying peers, Juichiro managed to fall asleep in the front row and his teacher did not even notice it.

In summary, the participants were "relaxed" at the Japanese school. Tomoko stated that she could "talk non-stop to Japanese friends like a machine gun" without thinking about consequences. Comparing both her Japanese and American friends, Natsuko said:

I have best friends at the U.S. school. But other peers are kind of mean there. Compared to them, everybody at the Japanese school is friendly, fun, and kind. Also, they eat the same things as I eat!

Haruko said, "Even though we talk stupid thing at the Japanese school, these stupid things themselves are fun to talk about. More relaxed!" Masako $\left(6^{\text {th }}\right.$ grade female) simply stated, "They are Japanese, so we do the same things. It is more comfortable and relaxing with Japanese friends."

What kind of food did they bring to lunch? Onigiri. Shiro admitted that he preferred onigiri to sandwiches. Yoko said, "Of course, Japanese food at the Japanese school! That's natural!"

After the school was over, the students dashed to the school parking lot to meet their parents. Since most of them had already arranged to go to their friends' house after school, they were telling their parents about this after-school plan. One mother was driving four students in the car so they could play at her house. Their parents were told to pick them up later. This practice was repeated every Saturday.

\section{Academic Performance in the Japanese School}

The academic performance at the Japanese school was in sharp contrast to that of the U.S. schools. The students who made such an effort to succeed academically at the U. S. schools did not study hard at the Japanese school and showed some of the same behaviors they had criticized about American students. The Japanese school was a place to socialize more and study less. 
The students were much less concerned about their grades. Kuro was not bothered by his grades when he said, "I'm behind in my studies at the Japanese school." Reiko contended, "I don't study for a test. I don't listen to teachers." Homework they always completed for the U.S. schools was also treated differently. Yoko laughed and stated, "I never do my homework for the Japanese school. I'm too busy with the homework for the U. S. school." Etsuko added, "Teachers don't care about homework, either." All the students agreed that the teachers at the Japanese school were not as demanding as those at the U.S. schools.

The higher academic level at the Japanese school may have contributed to the indifferent attitudes of the students toward their grades and study habits. The level was too high for the students to become motivated. Chikako described her mathematics class as "far more difficult than the U.S. school. The Japanese school is much more advanced." The Japanese language level was also a problem to them. Haruko said that she was having a hard time maintaining her Japanese language literacy. Social studies presented a cultural problem. Since the students were culturally adapted to the mainstream U.S. society, they had acquired only the limited amount of knowledge of the Japanese society. Consequently, as Natsuko expressed, "The history of Japan is foreign, but the U.S. history is familiar."

\section{Discussion}

The Japanese students in this study manifested a sharp contrast in their behaviors and academic performance in two different educational contexts. At the U.S. schools where they were the minorities, they socialized well among friends, yet were rather quiet and reserved. They were eager to study hard to surpass American peers and to meet the expectations of their teachers. Their behaviors and academic performance perfectly fit the model minority stereotype. On the contrary, at the Japanese school where they were the majority, they were relaxed, loud, and careless about academic success.

Their quietness and stellar academic performance at the U.S. schools could be interpreted as a self-defense act. Being such an extreme minority and consequently not being able to form a collective resistance force, the participants chose to render themselves culturally invisible so that any unnecessary harassment from peers would be lessened. At the same time, they were eager to gain positive evaluation through academic achievement and good personality. One student's comment exemplifies this: "Don't talk, just listen!" It seems that the model minority stereotype was deliberately reinforced by the adults, particularly teachers, and internalized by the participants themselves, confirming the observation of Chin and Chan (1971) that "the stereotypes assigned to the various races are accepted by the races themselves as reality, as fact" (p. 65). This is similar to Conchas' (2006) observation of Vietnamese students who accepted the stereotypes assigned to them as fact. 
Since academic learning was not emphasized at the Japanese school, its meaning became more symbolic than substantial, more social than academic. This symbolic nature of the school counterbalanced some of the negative effects of being such an extreme minority at the U.S. schools. The school offered a safe ethnic space where the participants could relax and relate naturally with each other since it was ethnically homogeneous and they were the majority there. Tsai's (2006) ethnography confirms this point and reveals that immigrant youth chose to live near an ethnic community because, as Zhou and Li (2003) state, "reconnecting with coethnics often helps ease psychological and social isolation" (p. 68). Because they were surrounded by mostly Whites and struggled to maintain a healthy sense of ethnic self during the weekdays, the affirming cultural environment on Saturdays was a welcomed relief. After all, one of the basic human needs is affiliation that can be afforded by those with common emotional experiences (De Vos, 1992).

The findings of this study suggest a unique function of an ethnic language school beyond the maintenance of language and culture. An ethnic language school functions as a valuable space to affirm ethnic socialization, which is crucial for minority students' psychological, emotional, and social well-being in the process of developing healthy ethnic identity. Minority students need to socialize ethnically/racially in order to respond to the environmental stress coming from the minority status. It is the ethnic peer group members with similar experiences that truly understand the psychological stress of being an extreme minority in a predominantly White school, confirming Tatum's (1997) claim that "the ability to see oneself as part of a larger group from which one can draw support is an important coping strategy" (p. 70); the culturally affirming support from and socialization with the ethnic peers at an ethnic language school provide minority students with a sense of personal security. This secure sense of self nurtured at an ethnic language school further becomes a foundation for a successful cultural navigation at a predominantly White school.

Ethnic socialization is sometimes impossible due to the number of students or frowned upon by the dominant group at regular U.S. schools. As a result, minority students have a difficult time developing a positive ethnic sense of self. Tatum (1997) warns that individuals who do not "experience a shared identity with at least some subset of their racial group are at risk for considerable social isolation" (p. 70). This social isolation leads to psychological and emotional isolation. It is ideal that a school provides minority students with the opportunity to socialize ethnically/racially, such as ethnically specific programs and organizations inside the school. If it is not possible, an ethnic language school will serve this purpose, particularly to language minority students. It is also important that these ethnically specific programs are not seen as voluntary self-segregation, but seen as culturally and psychologically affirming space.

It is important to investigate minority students' experiences outside the school to better understand them. The Japanese adolescents in this study never 
exhibited any misbehavior and were praised as model students at the U.S. schools. Everyone assumed that that was their actual portrayal. Who could imagine their totally opposite behavior and academic performance at the Japanese school? We educators need to be aware of minority students' psychological stress and the necessity for ethnic socialization no matter how well they appear to function at a predominantly White school.

\section{References}

Asato, N. (2006). Teaching Mikadoism: The attack on Japanese language schools in Hawaii, California, and Washington, 1919-1927. Honolulu, HI: University of Hawai'i Press.

Bennett, C. I. (2007). Comprehensive multicultural education: Theory and practice $\left(6^{\text {th }}\right.$ ed.). Boston: Pearson Allyn and Bacon.

Bogdan, R., \& Biklen, S. K. (2007). Qualitative research for education: An introduction to theory and methods ( $5^{\text {th }}$ ed.). Boston: Pearson Allyn and Bacon.

Chin, F., \& Chan, J. P. (1971). Racist love. In R. Kostelanetz (Ed.), Seeing through shuck (pp. 65-79). New York: Ballantine.

Conchas, G. Q. (2006). The color of success: Race and high-achieving urban youth. New York: Teachers College Press.

De Vos, G. (1992). Social cohesion and alienation: Minorities in the United States and Japan. Boulder, CO: Westview Press.

Erickson, E. H. (1980). Identity and the life cycle. New York: W. W. Norton.

Fought, C. (2006). Language and ethnicity: Key topics in sociolinguistics. Cambridge, UK: Cambridge University Press.

Jan, T. (2008, February 9). Asian students left behind on special education. The Boston Globe. Retrieved May 29, 2008, from http://www.boston.com/news/local/articles/2008/02/09/asian students left behind on special education/

Jourdan, C., \& Tuite, K. (2006). Introduction: Walking through walls. In C. Jourdan \& K. Tuite (Eds.), Language, culture, and society (pp. 1-15). Cambridge, UK: Cambridge University Press.

Lew, J. (2006). Asian Americans in class. New York: Teachers College Press.

Lee, S. J. (1996). Unraveling the "model minority" stereotype: Listening to Asian American youth. New York: Teachers College Press.

Lee, S. J. (2005). Up against Whiteness: Race, school, and immigrant youth. New York: Teachers College Press.

Merriam-Webster's Collegiate Dictionary (11 ${ }^{\text {th }}$ ed.). (2003). Springfield, MA: Merriam-Webster. 
Minoura, Y. (1984). Kodomono ibunka taiken: Jinkaku keisei kateino shinri jinruigakuteki kenkyu (Children's experiences of different cultures: Psychoanthropological study on the process of a personality formation). Tokyo: Shisakusha.

Morimoto, T. (1997). Japanese Americans and cultural continuity: Maintaining language and heritage. New York: Garland Publishing.

Padilla, A. (1999). Psychology. In J. A. Fishman (Ed.), Handbook of language and ethnic identity (pp. 109-121). Oxford, UK: Oxford University Press.

Poon-McBrayer, K. F., \& Garcia, S. B. (2000). Profiles of Asian American students with LD at initial referral, assessment, and placement in special education. Journal of Learning Disabilities, 33(1), 61-70.

Rotheram, M. J., \& Phinney, J. S. (1987). Introduction: Definitions and perspectives in the study of children's ethnic socialization. In J. S. Phinney \& M. J. Rotheram (Eds.), Children's ethnic socialization: Pluralism and development (pp. 10-28). Newbury Park, CA: Sage.

The Seattle Japanese School. (2008). Gakko no gaiyo. Retrieved May 27, 2008, from http://www.seajschool.org/Gaiyo.aspx

Sue, S., \& Okazaki, S. (1990). Asian-American educational achievements: A phenomenon in search of an explanation. American Psychologist, 45(8), 913-920.

Suzuki, R. H. (1980). Education and the socialization of Asian Americans: A revisionist analysis of the "model minority" thesis. In R. Endo, S. Sue, \& N. N. Wagner (Eds.), Asian Americans: Social and psychological perspectives (Vol. 2) (pp. 155-175). Ben Lomond, CA: Science and Behavior Books.

Suzuki, M. J. (2000). Child-rearing and educational practices in the United States and Japan: Comparative perspectives. Hyogo University of Teacher Education Journal, 20(1), 177-186.

Tatum, B. D. (1997). "Why are all the Black kids sitting together in the cafeteria?": And other conversations about race. New York: Basic Books.

Tobin, J. J., Wu, Y. H., \& Davidson, D. H. (1989). Preschool in three cultures: Japan, China, and the United States. New Haven, CT: Yale University Press.

Tsai, J. H-C. (2006). Xenophobia, ethnic community, and immigrant youths' friendship network formation. Adolescence, 41(162), 285-298.

U. S. Department of Education. (2004). Highlights from the trends in international mathematics and science study (TIMSS) 2003. Washington, D.C.: Author.

Zhou, M., \& Li, X-Y. (2003). Ethnic language schools and the development of supplementary education in the immigrant Chinese community in the United States. In C. Suarez-Orozo \& I. L. G. Todorova (Eds.), Understanding the social words of immigrant youth (pp. 57-73). San Francisco: Jossey-Bass. 


\section{Appendices}

Table 1. Student's Background

\begin{tabular}{|c|c|c|c|c|c|c|c|}
\hline \begin{tabular}{|c|} 
Name \\
(Pseudonym)
\end{tabular} & Age & Grade & Gender & $\begin{array}{l}\text { Birth } \\
\text { Place }\end{array}$ & Arrival Age to U.S. & US School & Future Plan \\
\hline Akiko & 13 & $8^{\text {th }}$ & Female & Japan & $\begin{array}{l}6 \text { years old; } \\
\text { Was in London from } \\
0-3 \text { years old }\end{array}$ & Public MS & Stay in U.S. \\
\hline Chikako & 15 & $10^{\text {th }}$ & Female & Japan & 12 years old & Public HS & $\begin{array}{l}\text { Will return to Japan, } \\
\text { but don't know } \\
\text { when }\end{array}$ \\
\hline Etsuko & 13 & $8^{\text {th }}$ & Female & U.S. & & Public JHS & Stay in U.S. \\
\hline Fuyuko & 14 & $9^{\text {th }}$ & Female & U.S. & & Public HS & Stay in U.S. \\
\hline Goro & 13 & $8^{\text {th }}$ & Male & U.S. & & Public MS & Stay in U.S. \\
\hline Hachiro & 13 & $7^{\text {th }}$ & Male & U.S. & $\begin{array}{l}\text { Was in Japan from 0- } \\
5 \text { years old }\end{array}$ & Public HS & Stay in U.S. \\
\hline Haruko & 13 & $8^{\text {th }}$ & Female & U.S. & & Private & Stay in U.S. \\
\hline Hichiro & 13 & $8^{\text {th }}$ & Male & U.S. & & Private & Stay in U.S. \\
\hline Ichiro & 13 & $7^{\text {th }}$ & Male & Japan & 2.5 years old & Public JHS & Stay in U.S. \\
\hline Jiro & 13 & $7^{\text {th }}$ & Male & Japan & 2.5 years old & Private & Stay in U.S. \\
\hline Juichiro & 14 & $10^{\text {th }}$ & Male & U.S. & & Public HS & Stay in U.S. \\
\hline Jujiro & 13 & $7^{\text {th }}$ & Male & Japan & 10 years old & Public MS & $\begin{array}{l}\text { Will return to Japan, } \\
\text { but don't know } \\
\text { when }\end{array}$ \\
\hline Juro & 13 & $8^{\text {th }}$ & Male & U.S. & & Public MS & Stay in U.S. \\
\hline Kuro & 14 & $9^{\text {th }}$ & Male & U.S. & $\begin{array}{l}\text { Was in Japan from 2- } \\
7 \text { years old }\end{array}$ & Public MS & Stay in U.S. \\
\hline Masako & 11 & $6^{\text {th }}$ & Female & Japan & 3 years old & Public MS & Stay in U.S. \\
\hline Natsuko & 12 & $6^{\text {th }}$ & Female & U.S. & & Private & Stay in U.S. \\
\hline Reiko & 17 & $11^{\text {th }}$ & Female & U.S. & & Public HS & Stay in U.S. \\
\hline Rokuro & 13 & $8^{\text {th }}$ & Male & Japan & 5 years old & Public MS & Stay in U.S. \\
\hline Saburo & 15 & $9^{\text {th }}$ & Male & U.S. & & Public HS & Stay in U.S. \\
\hline Sachiko & 15 & $10^{\text {th }}$ & Female & U.S. & $\begin{array}{l}\text { Was in Japan from 4- } \\
9 \text { years old }\end{array}$ & Public HS & Stay in U.S. \\
\hline Shiro & 14 & $9^{\text {th }}$ & Male & U.S. & & Public HS & Stay in U.S. \\
\hline Tomoko & 13 & $7^{\text {th }}$ & Female & U.S. & & Public MS & Stay in U.S. \\
\hline Yoko & 14 & $9^{\text {th }}$ & Female & Japan & 4 years old & Public HS & Stay in U.S. \\
\hline
\end{tabular}


Table 2. Teachers' Background

\begin{tabular}{|l|l|l|l|l|}
\hline \multicolumn{1}{|c|}{ Name } & Gender & \multicolumn{1}{c|}{ Subject Area } & \multicolumn{1}{c|}{ Location } & Matching Student's Name \\
\hline Caroline & Female & Language Arts & U.S. Public & Ichiro \\
\hline Christina & Female & English & U.S. Public & Goro \\
\hline David & Male & Social Studies & U.S. Private & Natsuko \\
\hline Elizabeth & Female & Language Arts & U.S. Private & Hichiro \\
\hline Hiroko & Female & Math & Japanese & Natsuko \\
\hline James & Male & Physical Ed. & U.S. Public & Masako \\
\hline Jerry & Male & Social Studies & U.S. Public & Juichiro \\
\hline Julie & Female & Math/Spanish & U.S. Public & Rokuro \\
\hline Machiko & Female & Japanese & Japanese & Natsuko \\
\hline Mary & Female & Religion/Math & U.S. Private & Yoko \\
\hline Nancy & Female & Language Arts & U.S. Public & Tomoko \\
\hline
\end{tabular}

